\title{
PROSPECTIVE TEACHERS' INTERPRETATIVE KNOWLEDGE ON EARLY ALGEBRA
}

\author{
CONHECIMENTO INTERPRETATIVO DE FUTUROS \\ PROFESSORES DA EDUCAÇÃO INFANTIL E ANOS INICIAIS \\ NO ÂMBITO DO PENSAMENTO ALGÉBRICO
CONOCIMIENTO INTERPRETATIVO DE FUTUROS PROFESSORES DE INFANTIL E PRIMÁRIA EN EL CONTEXTO DEL PENSAMIENTO ALGEBRAICO

\author{
Rosa Di Bernardo \\ PhD Student at Programa de Pós-Graduação Multiunidades em \\ Ensino de Ciências e Matemática (PECIM). UNCAMP - Brasil. \\ Istituto Comprensivo Madonna Assunta. \\ Naples - Italy. \\ rosadibernardo92@gmail.com \\ Gemma Carotenuto \\ $\mathrm{PhD}$ in Mathematics by the University of Salerno. \\ Università di Napoli Suor Orsola Benincasa. \\ Naples-Italy. \\ gemmacarotenuto@gmail.com \\ Maria Mellone \\ $\mathrm{PhD}$ in Mathematics at University Federico II of Naples (Italy). \\ Associate Professor at University Federico II of Naples. \\ Naples - Italy. \\ maria.mellone@unina.it \\ Miguel Ribeiro \\ $\mathrm{PhD}$ in Mathematics Education by the University of Huelva (Spain). \\ Associate Professor at Faculty of Education of UNICAMP - Brasil. \\ Campinas-SP, Brazil. \\ cmribas78@gmail.com
}

\begin{abstract}
Starting from the assumption that very young children exhibit some naive forms of algebraic skills, in this paper we discuss some of our work aimed at inquiry, and in the same time develop, prospective primary teachers' knowledge involved and required in recognize and interpret pupils' early forms of algebraic thinking. The research dimension is perceived intertwined with teacher education and practice and thus, the tasks we develop for such work focus on early years' prospective teachers' mathematical knowledge specifically related with the work of teaching Early Algebra. Thus, our focus of attention concerns their knowledge that would sustain the work on supporting the development of pupils' knowledge and reasoning toward more refined algebraic skills. We present promising preliminary results from an experiment conducted on 60 prospective Italian teachers', which paves the way for further research about the expected early years teachers' knowledge on Early Algebra and Algebra and even more refined didactic methods aimed at developing it.
\end{abstract}

Keywords: Teachers' knowledge. Algebraic Reasoning. Interpretative knowledge. Early years.

Resumo: Considerando que as crianças desde cedo possuem algumas capacidades, competências e conhecimentos algébricos, ainda que intuitivos, neste artigo discutimos uma parte de nosso trabalho que tem por objetivo acessar e desenvolver o conhecimento de futuros professores envolvido e requerido em reconhecer e interpretar produções de alunos no âmbito do Pensamento Algébrico. Pesquisa, formação e prática são consideradas de forma indissociada e, assim, as tarefas que conceitualizamos para desenvolver esse trabalho focam-se no conhecimento matemático de futuros professores especificamente relacionado com as tarefas de ensinar Pensamento Algébrico. Assim, o nosso foco de atenção refere-se, especificamente, ao conhecimento de futuros professores que contribua para o desenvolvimento do conhecimento e raciocínio dos alunos no sentido de refinar as suas competências algébricas. Apresentamos alguns resultados preliminares a partir da análise de uma tarefa para a formação de professores implementada em Itália a 60 futuros professores e que revelam alguns aspetos centrais do conhecimento do professor relativamente ao Pensamento Algébrico e à Álgebra e indicam necessidades de pesquisa que contribua para um desenvolvimento de tal conhecimento.

Palavras-chave: Conhecimento do professor. Pensamento Algébrico. Conhecimento Interpretativo. Anos Iniciais. 
Resumen: Considerando que los niños desde edad temprana poseen algunas capacidades, competencias y conocimientos algebraicos, aunque intuitivos, en este artículo discutimos una parte de nuestro trabajo que tiene por objetivo acceder y desarrollar el conocimiento de futuros profesores involucrado y requerido en reconocer e interpretar producciones de alumnos en el ámbito del Pensamiento Algebraico. Investigación, formación y práctica se consideran de forma indisociada y así, las tareas que conceptualizamos para desarrollar ese trabajo se enfocan en el conocimiento matemático de futuros profesores específicamente relacionado con las tareas de enseñar Pensamiento Algebraico. Nuestro foco de atención se refiere específicamente al conocimiento de futuros profesores que contribuya al desarrollo del conocimiento y raciocinio de los alumnos en y para refinar sus competencias algebraicas. Presentamos algunos resultados preliminares a partir del análisis de una tarea para la formación de profesores implementada en Italia a 60 futuros profesores y que revelan algunos aspectos centrales del conocimiento del profesor respecto al Pensamiento Algebraico y al Álgebra e indican algunas necesidades de investigación que contribuya a un desarrollo de dicho conocimiento.

Palabras claves: Conocimiento del profesor. Pensamiento Algebraico. Conocimiento Interpretativo. Educación Infantil e primaria

\section{INTRODUCTION}

In the last few years a lot of researches have highlighted the presence of naive forms of algebraic thinking in very young children (LEE; FREIMAN, 2004; RADFORD, 2010; CAI; NUTH, 2011; KIERAN; PANG; SCHIFTER; FONG NG, 2016). These studies have undermined the traditional view of unidirectional "ontogenetic" development from arithmetical to algebraic thinking, opening up new scenarios, and leaving room for new hypotheses in which a more complex relationship is formed between the two forms of thought (RADFORD, 2010).

Between the attempts to deepen children's abilities in mathematical generalization and in abstractions, different researching experiences have been developed concerning the study of children's skills during the first school years with numerical and figural pattern (look for example LEE; STACEY, 1989; LEE; FREIMAN, 2004; RADFORD, 2010). For example, Lee and Freiman (2004), show how also kindergarten school children undertake with enthusiasm working context with pattern, being able to easily recognize regularity, but at the same time showing difficulties in the final step of generalization control. Stacey in his work notices similar behaviour in some primary school pupils, who showed the presence of just partial generalization forms (STACEY, 1989).

Radford $(2010 ; 2011)$ adopts a different vision. Beyond to analyse some first forms of algebraic thought, his study faces the monitoring problem of their development in the conclusions. In other words, the relevant issue it's not just to identify what very young children can or cannot do. It is also (manly) how to facilitate the development and to improve these embodied forms and not symbolic ones of algebraic thought. In this direction, one of the crucial questions is: "which kind of early work leads to emergence of algebraic thought and how can we recognize it and to support its development?".

In fact, if from one side (as shown by the aforementioned researchers) it's recognized that very young children present some forms of algebraic abilities, on the other side, it's clear that the algebraic thought isn't present during the ontogenesis by chance and, in the same time, it is not a necessary consequence of cognitive maturation. To bring out the algebraic thought it's important to create some appropriate pedagogical conditions, and look for appropriate didactic contexts to teach Algebra in the very early years of children life is one of the most fascinating challenges of the current research in mathematics education.

In this scenario, our research aims at inquiry, and at the same time contribute for the development of, teachers' knowledge and the connected skills in order to recognize and suitable react to pupils' Early Algebraic Thinking. For this we refer to the theoretical framework of Mathematical Knowledge for Teaching (MKT), that, designed few years ago, has become one of the international fundamental reference to face specifically exigencies linked to the profession of mathematics teaching (BALL; THAMES; PHELPS, 2008). Complementarily, in the scope of our research the notion of Interpretative Knowledge has been developed. Such interpretative knowledge in perceived as the knowledge that support teachers' in giving sense and interpret pupils' mathematical productions, in order to provide a fruitful feedback having such students' productions has the starting point (RIBEIRO; MELLONE; JAKOBSEN, 2016).

Expanding some of the previous work we have been doing on teachers' interpretative knowledge on, for example, fractions (JAKOBSEN; RIBEIRO; MELLONE, 2014), or the power of ten (JAKOBSEN 
et al., 2016), in this paper we start a new trend on our research pathway by addressing prospective primary teachers' interpretative knowledge on Early Algebra. Pursuing such aim, and following the particular nature of the tasks that are required for accessing and developing teachers' interpretative knowledge (RIBEIRO; MELLONE; JAKOBSEN, 2013), we have designed a particular interpretation task where prospective teachers had to first solve a word problem with algebraic features and then to interpret some pupils' productions on that same problem and provide a fruitful feedback to such students' productions. After this individual or small group work, we engaged prospective teachers in a collective mathematical discussion on the task. Grounded on the theoretical rational of the research, we present a first analysis of prospective teachers' interpretations of students' productions which allows us to enhance some of the critical elements that are required to fulfil in research and thus reveal some possible future research pathways.

\section{THEORETICAL FRAMEWORK}

\subsection{Algebraic Thinking}

The design of this study followed a socio-cultural approach in which learning is conceived as a refinement of linguistic skills always deeply intertwined with the development of thinking and awareness (Vygotski, 1978). Our approach can be placed within the mathematics education research stream that tries to catch the complexity of the individual thinking as materialized in the body (by means of gestures, facial expressions, eyes movements, etc.) and in the use of signs and artefacts (RADFORD, 2011). In particular, we rely on the following Radford's tenet:

Learning consists of positioning oneself reflectively and critically in historical forms of action and thinking. Functionally speaking, learning is conceptualized in terms of processes of objectification-i.e., activity bound social processes through which the students encounter and grasp the historically-constituted forms of action and thinking (RADFORD, 2010, p. 73).

In this view, as opposed to mental cognitive approaches, thinking is not considered something that just happens 'in the head', but rather it is conceived as a social practice rooted in bodily movements and in the use of signs and artefacts (see e.g. ibid.).

According with the previous perspective, the analysis of pupils' behaviours rely on the notion of semiotic nodes, "pieces of the students' semiotic activity where action, gesture, and word work together to achieve knowledge objectification" (RADFORD et al., 2003, p. 56).

When considering a certain domain in mathematics education, several approaches can be considered. In the particular scope of Algebraic Thinking, we perceive it as a kind of "discourse" (inter/intrapersonal) in which we can recognize attention to structure and relationships, "[...] learners exhibit this type of attention when they begin to focus on what stays and what changes - that is, "becom[e] accustomed to considering invariance in the midst of change" (MASON; STEPHENS; WATSON, 2009, p. 13).

Bourbaki (1974) distinguishes three basic types of mathematical structures: the algebraic, the order and the topological ones. In particular, he expresses his vision of Algebra in this way:

It is no doubt the possibility of these successive extensions, in which the form of the calculations remained the same, whereas the nature of the mathematical entities subjected to these calculations varied considerably, which was responsible for the gradual isolation of the guiding principle of the modern mathematics, namely that mathematical entities in themselves are of little importance; what matters are their relations (BOURBAKI, 1974, p. xxi).

According with this idea, the symbolic systems and the transformations rules of the algebraic language emerge from structural relationships among elements whose nature has little importance. When the relationship is seen as instantiation of a property, the relation becomes (part of) a structure seen in terms of an agreed list of properties taken as axioms, from which other properties can be deduced (MASON et al., 2009).

The process of recognizing a particular relationship among elements of a set as instantiation of a general property, that means "seeing the general through the particular", is a core process in 
the learning of mathematics (MASON, 1996). It is strictly linked to the experience of 'examplehood', which allows the learners to recognize how different cases are subsumed under a general law. The students' recognition of a single fact as an example requires that they grasp the sense of what the example expresses, the enhancement of the features that make it 'exemplary' and the darkening of the features that make it particular. We agree with Davydov that observation and modelling of the relations between concrete continuous quantities can be a rich and effective examplehood context for the algebraic relationships, provided it is inserted in an accurate educational path. Indeed, as we claimed in the Introduction, our work is prompted by Davydov studies, where "features and potentialities of experiencing manipulation of quantities are deeply analyzed" (DAVYDOV, 1975; 1982). In these studies, the thesis that at the root of the algebraic structures, and of the concept itself of number, there is the notion of physical quantities is advanced. Nowadays this crucial idea is finding many followers all around the world (see for example SLOVIN; DOUGHERTY, 2004; IANNECE, MELLONE; TORTORA, 2010; SCHIMTTAU, 2011). From this thesis, Davydov derives the necessity to let pupils work with concrete quantities since the very beginning of the school path, by making manipulations on them and discovering relationships and properties, rightly before than working with numbers. Our proposal of combining Davydov's curriculum with the Radford theory of objectification arose from the hypothesis that the activities proposed by Davydov can support pupils in the process of objectification of algebraic language. In other words, we believe that the exploration of suitable contexts with concrete quantities can support pupils making their own sense to the algebraic language that embodies historical forms of thinking (RADFORD, 2010).

According to this approach, pupils firstly discover the properties of quantities in concrete materials, then they learn how to record these properties by means of representations and algebraic symbols, and finally, via suitable teaching mediations, they accomplish a mathematical analysis of the relationships. In this perspective, the additive structure is rooted in the experience of comparing two different quantities and of trying to make them equal by means of one of two actions: either to decrease the bigger one (subtraction) or to increase the smaller one (addition). In this situation, the crucial point is that in both cases the quantity to be added or subtracted is the difference between the two initial quantities.

\subsection{Mathematical knowledge for teaching and interpretative knowledge}

Since Shulman's (1986) work, teachers' knowledge with its specificities has received much attention in mathematics education communities around the world. When studying such specificities, several approaches can be taken. One approach is to consider the domain of Pedagogical Content Knowledge (PCK) as a core part (e.g., Krauss, Baumert and Blum, 2008). Another approach is to focus more on the specificities of the mathematical aspects of teachers' knowledge (e.g., Ball et al., 2008), recognizing in particular that teachers need a kind of mathematical knowledge different from that needed in other professions that is indeed called Mathematics Knowledge for Teaching (MKT), or to consider both PCK and the Subject Matter Knowledge as specialized (CARRILLO et al., 2013). For the specific goals we pursuit with this research we refer to the MKT conceptualization as a starting point for the way we perceive teachers' knowledge.

Figure 1 - Mathematical Knowledge for Teaching.

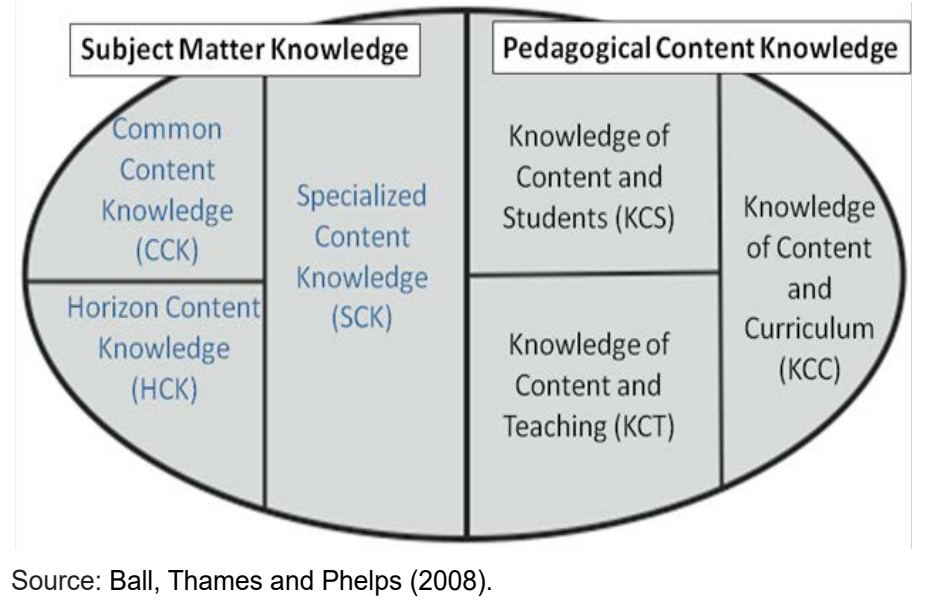

Cad. Pesq., São Luís, v. 24, n. Especial, set./dez. 2017 
One of the tasks of teaching is to make sense of students' solutions and help them to develop their mathematical knowledge. The knowledge involved in such a task, which we will call "interpretative knowledge", owns a peculiar and specific nature, and that also motivates our use of the MKT framework to investigate this particular dimension of prospective teachers' knowledge. In particular in our inquiry about interpretative knowledge we focus mainly on the Common and Specialized Content Knowledge (CCK and SCK) sub-domains of MKT. Indeed, in evaluating and giving sense to students' solutions of a mathematical task, the CCK, used both in teaching and in other settings that uses mathematics related at that specific mathematical topic, is of course fundamental. But in the same time this teachers' interpretative/evaluative work needs a specific SCK that does not concern Pedagogical Content Knowledge (PCK) and also differs from the mathematical knowledge commonly held by other professionals that use mathematics as a tool (CCK). Indeed, besides knowing a definition of a concept, how to solve a problem, or how to perform a certain calculation, it is essential that teachers also have knowledge allowing them to understand mathematical reasoning behind such calculation, definition, or problem-solving processes.

Teachers are required, thus, to possess a rich and ample knowledge of examples, strategies, and representations for problem solving that allows them to make sense not only of solutions similar to their own, but also of students' answers, reasoning, and strategies even very different from their own. In order to characterize and study the features of teachers' interpretations of students' productions, the notion of interpretative knowledge was introduced (see for example Ribeiro, Mellone and Jakobsen, 2016). The interpretative knowledge was defined as the knowledge that grounds teachers to be able to give sense to pupils' answers, in particular to "non-standard" ones, i.e., adequate answers that differ from those teachers would give or expect, or answers that contain errors. We posit that interpretative knowledge is closely related to the ability of teachers to support the development of pupils' mathematical knowledge, starting from their own reasoning, even if students' ideas are incomplete or are non-standard. Some similar ideas are implied in the notion of "discipline of noticing" (MASON, 2002). In particular, this construct encompasses the idea of teachers working "on becoming more sensitive to notice opportunities in the moment, to be methodical without being mechanical" (MASON, 2002, p. 61). The development of pupils' mathematical knowledge starting from their own reasoning is only possible if the teacher activates a real process of interpretation, shifting from a simple evaluative listening to a more careful hermeneutic listening (DAVIS, 1997).

In this sense, the notion of interpretative knowledge incorporates into the MKT framework the idea that errors and non-standard reasoning are considered as learning opportunities (BORASI, 1996). Moreover, the content of interpretative knowledge shapes teachers' ability to make informed choices in contingency moments (as defined by Rowland, Huckstep and Thwaites, 2005), in order to respond to and deal with non-planned situations.

In Webster dictionary, "interpretation" is defined as "The act of interpreting, explanation of what is obscure"; however, it is also defined as "An artist's way of expressing his thought or embodying his conception of nature." This last definition stresses the potential creative nature of the act of interpreting that is in our context perceived as the potential new mathematical knowledge that can be developed owing to the process of analysing students' productions.

\section{CONTEXT AND METHOD}

In this scenario, this work wants to explore teacher education contexts where there is an explicit aim of promoting teachers' knowledge development assuming a practice-based approach. These contexts pinpoint to the need for developing alternative approaches (didactic contexts) adapted to bring out early algebraic thought forms from pupils and aimed at developing prospective teachers' knowledge in and for dealing with such algebraic thoughts. At the same time, one of the project aims concerns the nature, focus and kind of the tasks for teacher education (task design aimed at developing teachers' interpretative knowledge). With these assumptions, the goal is to develop teachers' interpretative skills to recognize and work on leading to enrich the possibilities for the development of Early Algebraic thought forms in pupils.

Here we discuss a task that has been designed aimed at addressing different aspects of teachers' knowledge on early algebraic reasoning, but assuming a practice-based approach. The task was implement in a Mathematics Education course for prospective primary teachers at an Italian 
University during a 3 hours class, involving about 180 students divided into 60 small cooperative groups, having from 1 to 4 components.

The task was conceptualized starting from "Carletto's problem", which concerns a kind of problem that primary students are supposed to be able to solve:

Carletto is a child and has a sweet tooth. He has a box with 28 candies inside. Every day he eats twice as many candies as in the previous day. In three days Carletto has eaten all the candies. How many candies Carletto has eaten in each day? Explain your reasoning and try to make a representation that allows others to understand your reasoning.

This task was used as a tool to understand prospective teachers' MKT current level as well as a tool to support the development of prospective teachers' MKT, with particular attention to interpretative knowledge and feedback focus and ability. For doing so, the task consists of two parts. In Part I, prospective teachers were asked to solve Carletto's problem. They should just solve the problem, without thinking on how the students might solve it. In Part II, prospective teachers were asked to interpret, give meaning and provide a feedback to four students' problem resolutions.

The students' productions included in the task have been gathered from primary students' real answers to the same problem - the four productions included have been selected for particular reasons and the sequence in which they are included on the task is linked with different mathematical aspects which one can draw the solvers attention to.

Afterwards, prospective teachers were engaged in collective mathematical discussion - which was been audio-recorded - on the same interpretation task in order to allow a refinement and a development of their interpretative knowledge, skill, ability of noticing. This discussion was led from the viewpoint of the MKT and Early Algebra presented on the previous sections.

Here we present the request by which prospective teachers were asked to give sense to the four different pupil's productions and only two of these productions (Figure 2) (on the analysis and discussion we will focus only on Luca's one):

1. Consider the following students production to the previous problem.

i) Comment each one of the students' productions and indicate if (and why) you consider it mathematically correct or not, and justify the adequacy or inadequacy of the mathematical rationality shown (that you notice).

ii) Provide a fruitful feedback to the students' productions aiming at allowing developing students mathematical knowledge starting from what they already know - that you notice - and their reasoning (define a set of possible questions that you would pose to those pupils).

Figure 2 - Two examples of pupil's productions included in Part II

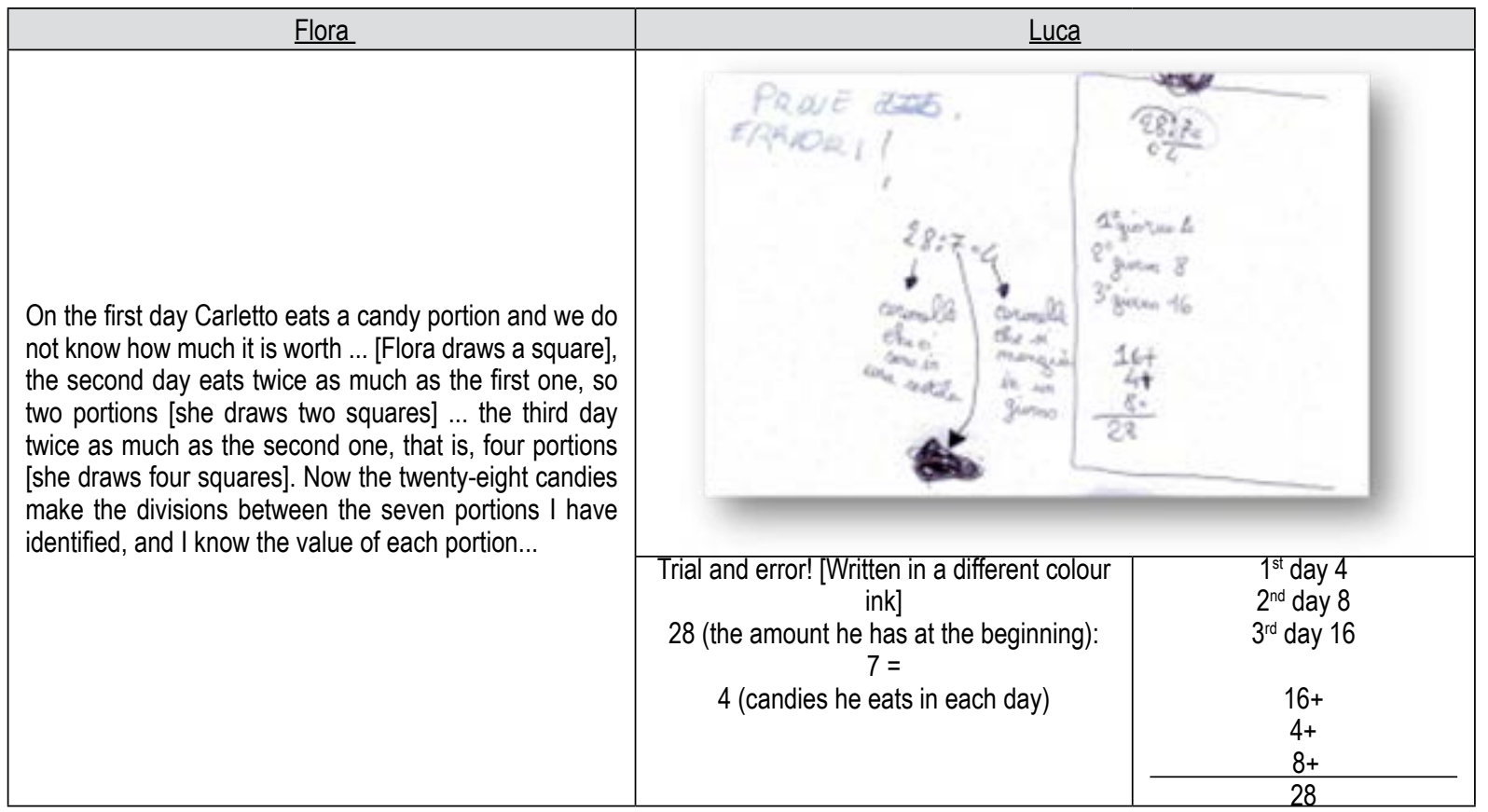

Source: Educational and research resources produced by the authors. 
On the analysis, we have looked at communalities and differences between clusters of prospective teachers' groups answers. Firstly, we have analysed the answers to the problem posed in Part I and five types of clusters of answers where found:

a) The answer explicitly refers to the trial and error method;

b) The answer explicitly recurs to the equation $x+2 x+4 x=28$;

c) The answer explicitly refers to 7 candies "portions", without recurring to the equation of type b);

c) The answer explicitly refers to an "intuition";

d) The answer is graphically reached (using "boxes"), paying attention to a certain structure for distributing the candies.

The focus on discussing these clusters of prospective teachers' answers was on their subject matter knowledge, and in particular on their Common Content Knowledge (CCK) and Specialized Content Knowledge (SCK), as such subdomains are perceived as the ground in which the interpretative knowledge is sustained - assuming the MKT conceptualization.

Only afterwards we address our attention to the second part of the task. The analysis of prospective teachers revealed interpretative knowledge and feedback provided to each one of the students' productions. For doing so we looked at the provided interpretations with a lens of the dimensions of the interpretations process identified in some of our previous work (JAKOBSEN et al., 2016), considering three categories as a starting point:

i) absence of interpretation of students' solving processes: when no comment is made for students' productions or when prospective teachers explicitly mention they cannot interpret it;

ii) interpretation of students' solving processes as incorrect: when words like "incorrect", "not right", "wrong", "error", "mistake", or "inadequate" appear in the comments concerning all or part of the solving process presented;

iii) interpretation of students' solving processes as correct: when words like "correct", "right", or "adequate" appear in the comments concerning all or part of the solving process presented.

One of the aims was also better understand the different approaches prospective teachers assume in the interpretation process as the context here was slightly different from the one involved in (JAKOBSEN et al., 2016). Even if remaining on the thematic context of Numbers, there was a movement from secondary prospective teachers' interpretative knowledge on the power of ten to a focus on prospective primary teachers' knowledge on Algebraic Reasoning.

\section{ANALYSIS AND DISCUSSION}

\subsection{Part I}

In this paper, we mainly concentrate our attention on the analysis and the discussion of prospective teachers' answers to the first part of the task, which we present in this subsection. The ongoing research on the answers to the second part, of which we anticipate some results in subsection 4.2 , and the analysis of the collective discussion are going to be presented in a following paper.

Amongst the 60 prospective teachers' groups answering the task, only one provided an incorrect answer to the problem of Part I - recall it concerns a problem that primary students are supposed to be able to find the correct solution. Such incorrect answer considers as solution the three numbers: 7 , 14 and 28 . The 59 remaining answers were analysed in order to recognize the underlying reasoning, which was identified in 48 cases.

These clusters of answers are presented and discussed here considering the descending order of occurrence (they have been presented on the previous section by this same order):

\section{a) The answer explicitly refers to the trial and error method}

From the 48 prospective teachers' groups who provided a correct answer and showed their reasoning, 20 adopted a trial and error strategy (explicitly or implicitly). Moreover, all prospective teachers' groups using such approach had a similar strategy: they started by considering two candies for the first day and increased the amount of candies eaten the first day by one twice, until the sum of the candies on the three days was the given amount of 28 candies. 
Figure 3 - Example of a trial and error strategy ("Starting from 2 I calculate the double of each number for three times, and I see which sum reaches 28 ")

\section{Prova a risolvere il problema.}

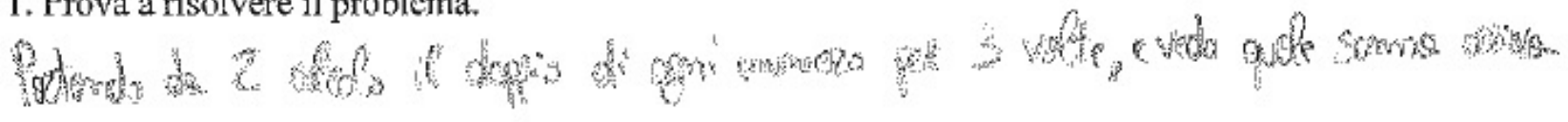

角, 2 :

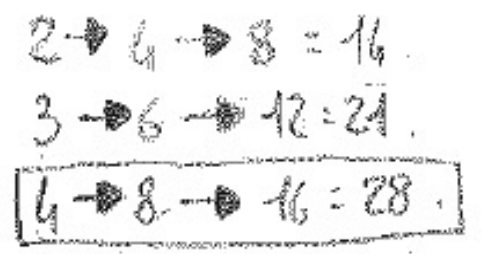

Source: Data from the implementation of the task with early years prospective teachers' in the scope of a Mathematics Education course.

We have to note that this strategy does not necessarily pays attention to the structure of the problem nor of the mathematics involved (MASON; STEPHENS; WATSON, 2009; BOURBAKI, 1974), as prospective teachers just increase by one the number of eaten candies on the first day. When being in possession of a knowledge that would allow the solvers to pay attention/focus on the structure, one would be able to consider a representation (as the one they draw in Figure 3) to go directly from the first possibility to the correct answer, which is at the basis of the effective use of the trial and error strategy - start from any initial number (trial) in order to obtain a first result expectably incorrect (error) but in order to pay attention to the structure in order to be able to devise the winner strategy (which is not thus associated with trying all the possibilities. Such kind of knowledge that would enable prospective teachers to have payed attention to the structure is perceived as CCK, as it was supposed to be a knowledge at the same level of the one students are required to be in possession of when solving problems aimed at discussing and developing some dimensions of their Algebraic Reasoning. This is also an example of the possible role of the trial and error strategy in and for developing an attention to the mathematical structure of the situation/problem, as one needs to mobilize its knowledge in order to be able to give meaning to what is happening along the process, and on the hows and whys such is happening. Being able to promote such movement in solvers (students') knowledge and focus of attention (MASON, 2002; RIBEIRO; BADILLO; SANCHEZMATAMOROS; MONTES; GAMBOA, 2017) requires a mathematical knowledge which is specific of the work of teaching, and thus, is part of SCK.

\section{a) The answer explicitly recurs to the equation $x+2 x+4 x=28$}

Recurring explicitly to the algebraic equation has been the strategy explicitly used by 19 prospective teachers' groups. They just consider $x$ (the unknown) as the amount of candies Carletto would eat at the first day, and assigned twice and four time as many candies as the first day to the second and the third day, respectively. 
Figure 4 - Example of an algebraic approach ("x = candies $1^{\circ}$ day").

1. Prova a risolvere il problema.

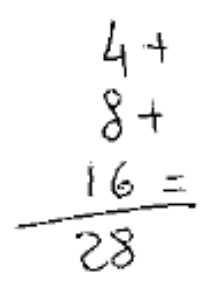

\section{$\cos 200000 \cos$

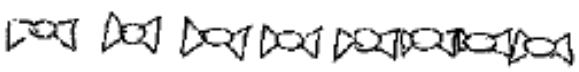

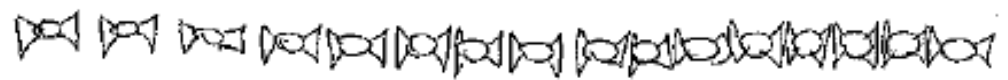

$$
\begin{aligned}
& x+2 x+2 \cdot(2 x)=28 \\
& 7 x=28 \quad x=\text { earamale } 109 . \\
& x=4
\end{aligned}
$$

Source: Data from the implementation of the task with early years prospective teachers' in the scope of a Mathematics Education course.

When solving the problem these prospective teachers made use of their CCK on equations, being able to "translate" from the word problem to the algebraic expression. The majority (12) also feel the need to provide a graphical representation in order to illustrate the result of the algebraic process (for example, in the Figure 5 protocol we find a pictorial representation), but only a few (4) where able to do it with correspondence between the algebraic expressions and the pictorial representation. Navigating fruitfully thorough different representations is perceived as one of the core elements of teachers' knowledge (RIBEIRO, 2011), being part of teachers' SCK.

\section{b) The answer explicitly refers to 7 candies "portions", without recurring to the equation of type b)}

The role of the seven in the process of solving the problem was a critical element enhanced by six prospective teachers' groups, but without recurring to the algebraic equation.

Figure 5 - Example of an approach grounded in algebraic reasoning (“ $1^{\circ}$ day $=4,2^{\circ}$ day $=8 ; 3^{\circ}$ day $=16$. I represent the days using a unit and using it to divide the days. In total, we have 7 units that we have to divide in 28 candied and we obtain as result $4 . ")$.

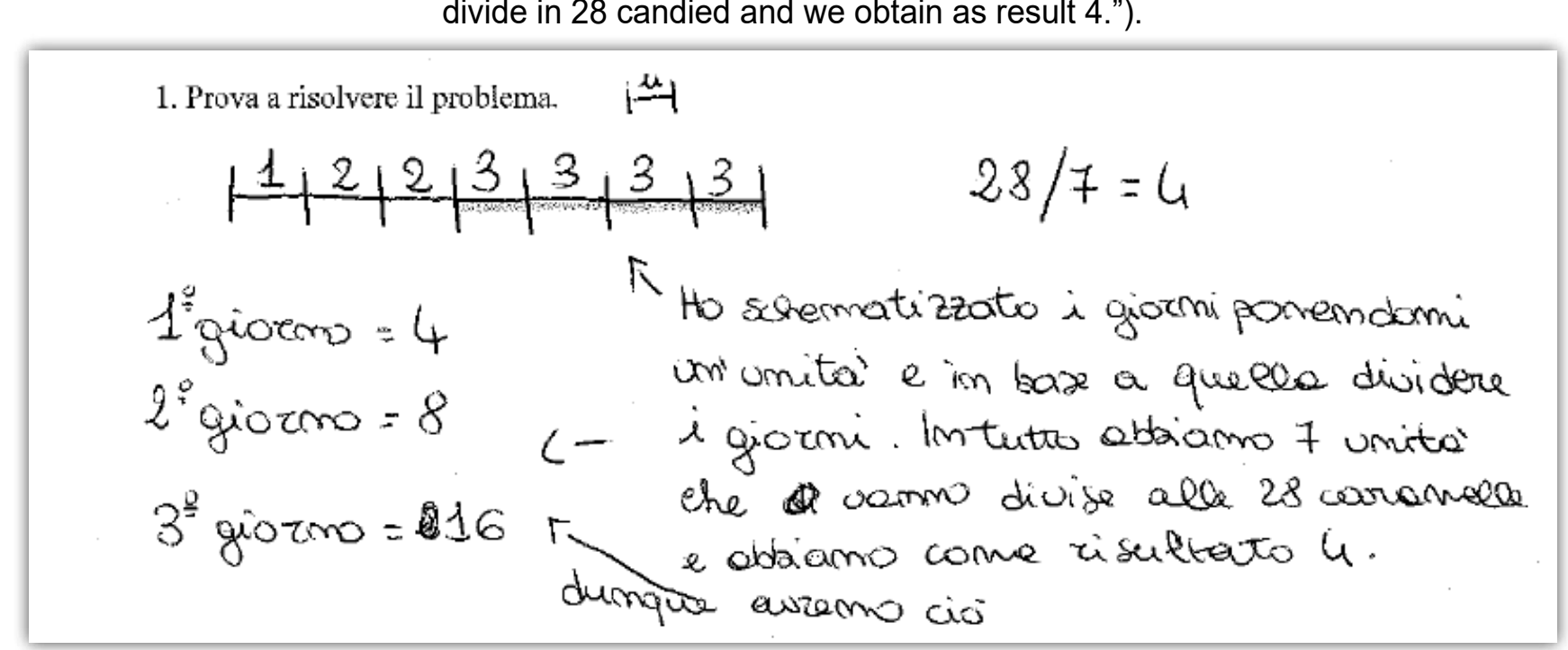

Source: Data from the implementation of the task with early years prospective teachers' in the scope of a Mathematics Education course.

Such kind of approach takes a different view point from the majority of the prospective teachers' explicit approaches (the previously presented approaches refer to 39 out of 48). When perceiving the seven as the core element of the strategy for solving the problem, prospective teachers are paying attention to the relationships between the quantities (DAVYDOV, 1975; 1982; IANNECE; MELLONE; TORTORA, 2010; SCHIMITTAU, 2011; SLOVIN; DOUGHERTY, 2004) and relate such quantities with the whole, mobilizing also some dimensions of their knowledge on fractions (PINTO; RIBEIRO, 
2014) - even if only intuitively. In the production shown in Figure 5, the prospective teachers' group revealed also knowledge on give meaning to the numbers used - here representing the relationship between the total amount of candies (the whole) and the quantities corresponding to each day - and the measurement process (CLEMENTS; STEPHAN, 2004), which can be perceived as an element of their SCK on fractions and measurement. Such fact enhances also the intertwined nature of teachers' mathematical knowledge required for teaching, as the context was of a problem dealing with aspects of Algebraic Reasoning but many other interconnected topics appear (connections here perceived in the sense of Montes, Ribeiro, Carrillo and Kilpatrick, 2016).

\section{c) The answer explicitly refers to an "intuition"}

Figure 6 - Example of an answer which explicitly refers to an "intuition" ("day $1=4$ candies, day $2=8$ candies, day $3=16$ candies. Intuitively and using multiples of 4 ")



Source: Data from the implementation of the task with early years prospective teachers' in the scope of a Mathematics Education course.

Two prospective teachers' groups attributed their answers to an intuitive thought, which in the protocols appear validated by a calculation. Such "intuition" is perceived as grounded in some aspect of their CCK which can be, in turn, related with the "lucky" use of the trial and error strategy that produced a correct answer on the first try.

\section{d) The answer is graphically reached (using "boxes"), paying attention to a certain structure for distributing the candies.}

Finally, just one prospective teacher, which worked individually, explicitly recurred to a mainly graphical different strategy which enhances a particular meaning given to the mathematical structure of the problem. 
Figure 7 - Example of a graphically reached answer, using "boxes" (" $1^{\circ}$ day= 4 candies, $2^{\circ}$ day $=8$ candies, $3^{\circ}$ day $=16$ candies. I took 28 candies and I imaged to have to share it in three bags, each one the double of the other. By putting one candy in the first bag, the double in the second bag and still the double in the third bag until the candies finish I realize that the result is $=4-8-16 ")$.

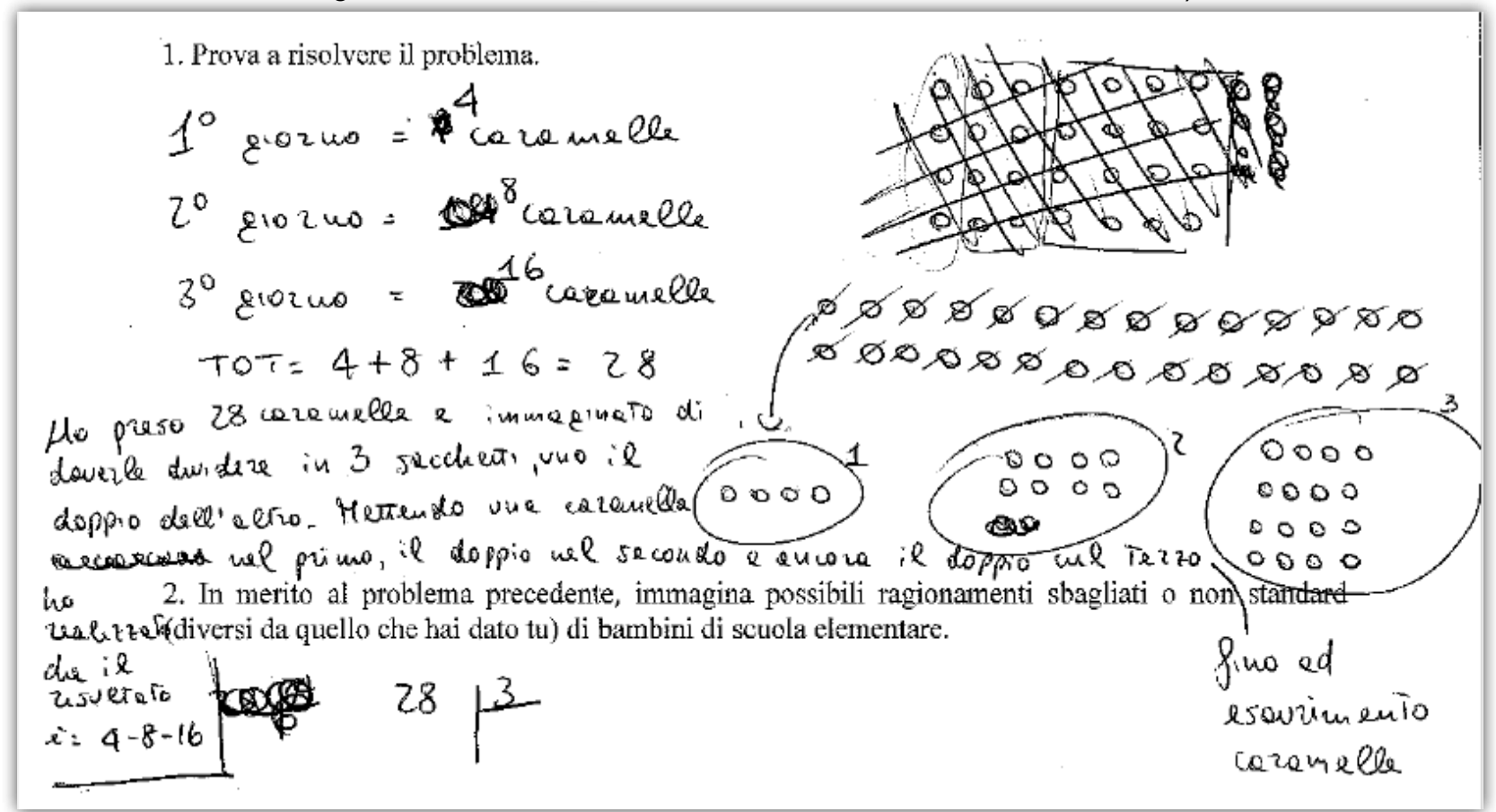

Source: Data from the implementation of the task with early years prospective teachers' in the scope of a Mathematics Education course.

It consists in considering three imaginary candy boxes to be filled by recursively adding 1,2 and 4 candies to the first, the second and the third box, respectively, until the 28 available candies - iconically represented above the boxes in Figure 7 - finish. We notice that this is the only solution in which the unknown candies number of the first day, which other group usually denoted by $\mathrm{x}$, does not play a different role with respect to the unknown candies numbers of the second day and the third day. In fact, here the value of $x$ semantically corresponds to the number of times each box is filled.

Table 1 - Summary scheme of the categories distribution of the prospective teachers' groups' answers

\begin{tabular}{|c|l|c|}
\hline Categories & \multicolumn{1}{|c|}{ Categories descriptions } & Numbers of answers \\
\hline a) & The answer explicitly refers to the trial and error method & 20 \\
\hline b) & The answer explicitly recurs to the equation $x+2 x+4 x=28$. & 19 \\
\hline c) & $\begin{array}{l}\text { The answer explicitly refers to 7 candies "portions", without recurring to the equation of } \\
\text { type b) }\end{array}$ & 6 \\
\hline d) & The answer explicitly refers to an "intuition" & 2 \\
\hline e) & $\begin{array}{l}\text { The answer is graphically reached (using "boxes"), paying attention to a certain structure } \\
\text { for distributing the candies }\end{array}$ \\
\hline
\end{tabular}

Source: Data from the research analysis .

We note that only 26 answers (over the 59 correct ones) are of type b) and c), and thus are classifiable as "algebraic" or "proto-algebraic". A possible interpretation of the lacking resort to Algebra is traceable in the quantities involved in the word problem (28 candies and 3 days), whose small size could have influenced prospective teachers to choose more ingenuous strategies.

On the other side, we have to consider also another situation: amongst all the non-algebraic answers, including the 11 for which it was impossible to identify a problem solving strategy (33), 28 contain a graphical representation, but none of them contain any representation that refers to the unknown number of eaten candies on the first day or to elements identifiable as "candies portions". This observation does not allow to exclude the worrying hypothesis that for the majority of the prospective teachers their non-algebraic strategy was not the "cheapest" one for the problem, but the only feasible way with their mathematical tools - which would correspond, in terms of the ideas of the Interpretative knowledge, to be in possession of a space of solution with a single element. Such 
an hypothesis is also supported by the data emerging from the collective discussion on Part I, which we do not analyse here, and from the answers to Part II, partially analysed in the next subsection.

\subsection{Part II}

We present now some preliminary results of the analysis of the answers to Part II, considering only the prospective teachers comments to Luca's production (Figure 2).

In general, there have been very few answers to Part II: in fact, 54 (of 60) prospective teachers' groups productions are included in the category (i) absence of interpretation of students' solving processes - see Section 3 - since they do not comment any of the four pupils' productions included in the task. Such fact might be due to the unexpected amount of time that took them to answer to Part I, leaving just few minutes to dedicate to Part II, which - in addition - was largely and openly perceived as demanding.

Focusing on prospective teachers' comments and/or provided feedback to Luca's protocol, even if few, several comments arise from its analysis. Firstly, we have to note some interesting aspect of this student production (which was one of the reasons why it was included on the task), since its complete understanding and a fruitful feedback to it require the type of CCK and SCK on which we are inquiring, namely a suitable interpretative knowledge on Algebra intertwined with Algebraic Reasoning. In fact, on the left part of Luca's production its shown an early algebraic form of thought: he writes the division $28: 7=4$, specifying that 28 is the number of the "candies contained in a box" and 4 is that of the "candies [Carletto] eats in a day". Moreover, Luca probably attempts to give sense to the 7 (above this number something has been erased), but in the protocol the semantic meaning of 7 is not explained. Thus, a teacher intervention aimed at develop this naïve algebraic reasoning should be oriented to support Luca in completing the semantic meaning of its division and in refining the scientific language used in the description of the number 4. For doing so questions addressing expanding Luca's understanding on the role of the seven and in using a mathematically valid and adequate language - both for the seven and the four. A teacher who does not possess an adequate algebraic mastery cannot succeed in this work, and for doing so, elements of teachers' SCK are required (JAKOBSEN; RIBEIRO; MELLONE, 2014).

Just 5 prospective teachers' groups wrote something about Luca's protocol: of these, 3 have been recognize to belong to category (ii) interpretation of students' solving processes as incorrect and the others to category (iii) interpretation of students' solving processes as correct.

Groups whose answer falls into the category (ii), namely those that evaluate Luca's production as incorrect, showed that they could not give a semantic meaning to Luca's division. For example, one group wrote: "Luca is wrong because it is not clear where the division comes from, even if the result is correct". In support of this thesis, we noticed that in Part I one of these 3 groups were amongst the ones who adopted the trial and error method, and the other two groups were amongst the ones who did not show their solution process/reasoning.

The two prospective teachers' groups that provided a feedback that fits category (iii), sustain their feedback on the fact that on Luca's production there is no explanation of the use of the dividend 7. We interpret these type of comment as a feedback that these prospective teachers would give to Luca. For example, one group wrote: "It's correct but it's necessary to ask to Luca how he got the number 7 that divides the total of 28". We specify that the answers given in Part I by both groups fall in type c), thus these prospective teachers' groups are supposedly aware of the meaning of division performed by Luca.

\section{FINAL COMMENTS}

Interpretative knowledge is an essential requisite in and for dealing with every mathematical teaching context which is aimed at favouring active learning processes, appropriately supported by a teacher guide able to construct mathematical skills starting from students own reasoning. In the core of our research and education work, aiming at designing and implementing tasks contributing for improving teachers' knowledge and practices, there are more and more evidences on the need to work on interpretative knowledge not only in a transversal way, but also with practice-based teacher activities specially designed for this purpose (JAKOBSEN, et al., 2014), being the work we discussed here one of such evidences. 
We have explored teachers' knowledge in and for answering a particular task aimed at developing prospective primary teachers' knowledge on Algebra, being the one required to bring out the early algebraic thought forms which, in the last few years, have been highlighted in very young children by the international research (see, for example, Cai and Knuth, 2011). This preliminary study on Algebraic Reasoning mobilized and revealed when answering the particular practice-based task we have designed, enhances prospective primary teachers' lack of mastery in Algebra and on Algebraic Reasoning, pointing out the need for a particular focus of attention when aiming at focusing teacher education where it is most needed, allowing teachers to be able to promote early algebraic approaches with young children, starting from their reasoning and argumentations. Such aspect of teachers' knowledge (often with some problematic aspects), in fact, causes great difficulties in interpreting non-standard pupils reasoning, and thus in giving them constructive feedbacks.

This work paves the way for further research on (prospective and in practice) teachers' knowledge on Algebra and Algebraic Reasoning and even about more refined didactic methods/ approaches aimed at developing it. Beyond continuing the analysis of the activity presented here, a further step, would be, for example, to propose a slightly modified version of Part II of the task, in which there is an explicit request of identifying any sign of Algebraic Reasoning and to analyse the new answers which would contribute with new incomes both for the area of teachers' knowledge as well as for the task design dimension. 


\section{REFERENCES}

BALL, D.L.; THAMES, M.H.; PHELPS, G. Content knowledge for teaching: What makes it special? Journal of Teacher Education, v. 59, n. 5, p. 389407. 2008.

BORASI, R. Reconceiving mathematics instruction: A focus on errors. Norwood, NJ: Ablex Publishing Co, 1996.

BOURBAKI, N. Algebra I. Addison-Wesley, Reading, Massachusetts, 1974.

CAI, J.; KNUTH, D. (a cura di) Early Algebraization: A Global Dialogue from Multiple Perspectives. Springer, 2011.

CARRILLO, J.; CLIMENT, N.; CONTRERAS LC.; MUÑOZ-CATALÁN, M. C. Determining specialised knowledge for mathematics teaching. In B. Ubuz, C. Haser, \& M. A. Mariotti (Eds.), Proceedings of CERME 8 (p. 2985-2994). Antalya, Turkey: ERME, 2013.

CLEMENTS, D. H.; STEPHAN, M. Measurement in pre-K to grade 2 mathematics. Engaging Young Children in Mathematics: Standards for Early Childhood Mathematics Education. New Jersey: LEA: D.H. Clements, J. Sarama, \& A-M Di Biase, (p. 299317), 2004.

DAVIS, B. Listening for differences: An evolving conception of mathematics teaching. Journal for Research in Mathematics Education, v. 28, n. 3, p. 355-376, 1997.

DAVYDOV, V. V. Logical and psychological problems of elementary mathematics as an academic subject. In L. P. Steffe (ed.), Children's capacity for learning mathematics. Soviet Studies in the Psychology of Learning and Teaching Mathematics, Vol. VII (p. 55-107), University of Chicago, 1975.

DAVYDOV, V. V. The psychological characteristics of the formation of elementary mathematical operations in children. In T.P. Carpenter et al. (eds.) Addition and Subtraction: A cognitive perspective. Hillsdale, NJ: Lawrence Erlbaum, (p. 224-238), 1982.

IANNECE, D.; MELLONE, M.; TORTORA, R. Early multiplicative thought: a kindergarten path. In Pinto, M. F. \& Kawasaki, T. F. (eds.). Proceedings of the 34th Conference of the International Group for the Psychology of Mathematics Education, v. 3, p. 121128. Belo Horizonte, Brazil: PME, 2010.

JAKOBSEN, A.; RIBEIRO, C. M.; MELLONE, M. Norwegian prospective teachers' MKT when interpreting pupils' productions on a fraction task. Nordic Studies in Mathematics Education NOMAD, v. 19. n. 3-4, p. 135-150, 2014.
JAKOBSEN, A. et al. Discussing secondary prospective teachers' interpretative knowledge: A case study. In C. Csíkos, A. Rausch, \& J. Szitányi (Eds.), Proceedings of the 40th Conference of the IGPME, v. 3, p. 35-42. Szeged, Hungary: PME, 2016.

KIERAN, C.; PANG, J.; SCHIFTER, D.; FONG NG, S. Early Algebra, Research into its Nature, its Learning, its Teaching. ICME 13 Topical Survey, Springer, 2016.

KRAUSS, S.; BAUMERT, J.; BLUM, W. Secondary mathematics teachers' pedagogical content knowledge and content knowledge: Validation of the COACTIV constructs. ZDM, 40, p. 873-892, 2008.

LEE, L.; FREIMAN, V. Tracking primary students' understanding of patterns. In D. McDougall \& J. Ross (a cura di), Atti del 26th PMENA, v. 2, p. 245251. Toronto, Canada, 2004.

MASON, J. Expressing generality and roots of algebra. In N. Bernardz, K. Kieran and L. Lee (eds.), Approaches to Algebra, Dordrecht: Kluwer Academic Publisher, p. 65-86, 1996.

MASON, J. Researching your own Practice: The discipline of noticing. London: RoutledgeFalmer, 2002.

MASON, J.; STEPHENS, M.; WATSON, A. Appreciating mathematical structure for all. Mathematics Education Research Journal, v. 21, n. 2, p. 10-32, 2009.

MONTES, M; RIBEIRO, M.; CARILLO, J.; KILPATRICK, J. Understanding mathematics from a higher standpoint as a teacher: an unpacked example. In. Proceedings of the 40th Conference of the International Group for the Psychology of Mathematics Education; v. 3, p. 315-322. Szeged, Hungary: PME, 2016.

PINTO, H.; RIBEIRO, M. Conhecimento de futuros professores dos primeiros anos sobre os diferentes significados das frações. Revista de Educação Matemática, v.129, p. 19-22, 2014.

RADFORD, L. Elementary form of algebraic thinking in young students. In Pinto, M. F. \& Kawasaki, T. F. (a cura di). Atti del 34th Conference of the International Group for the Psychology of Mathematics Education, v. 4, p. 73-80. Belo Horizonte, Brazil: PME, 2010.

RADFORD, L. Embodiment, perception and symbols in the development of early algebraic thinking. In Ubuz, B. (a cura di), Atti del $f$ the 35th Conference of the International Group for the Psychology 
of Mathematics Education, v. 4, p. 17-24. Ankara, Turkey: PME, 2011.

RADFORD, L. et al. Calculators, graphs, gestures, and the production meaning. In N., Pateman, B. Dougherty and J. Zilliox (eds.), Proceedings of the 27 Conference of the International Group for the Psychology of Mathematics Education (PME27 PMENA25), v. 4, p. 55-62, 2003.

RIBEIRO, M. Abordagem aos números decimais e suas operações: a importância de uma eficaz navegação entre representações. Educação e Pesquisa (USP. Impresso), v.37, p.407-422, 2011.

RIBEIRO, M.; BADILLO, E.; SANCHEZ-MATAMOROS, G.; MONTES, M.; GAMBOA, G. Intertwining noticing and knowledge in video analysis of self practice: the case of Carla. In: CERME9, 2017, Dublin. Proceedings CERME 9, 2017. pp. to appear

RIBEIRO, C. M.; MELLONE, M.; JAKOBSEN, A. Give sense to students' productions: a particular task in teacher education. In: PROCEEDINGS OF THE INTERNATIONAL SYMPOSIUM, ELEMENTARY MATHEMATICS TEACHING (SEMT), 2013, Prague: Charles University. Anais... Prague: Charles University.: [s.n.], p. 273 - 281. 2013.

RIBEIRO, C. M., MELLONE, M.; JAKOBSEN, A. Prospective teachers' knowledge in/for giving sense to students' productions. In A. M. Lindmeier \& A. Heinze (Eds.), Proc. 37th Conference of the International Group for the Psychology of Mathematics Education, v. 4, p. 89-96, Kiel, Germany: PME, 2013.
RIBEIRO, C. M.; MELLONE, M.; JAKOBSEN, A. Interpretation students' non-standard reasoning: insights for mathematics teacher education. For the Learning of Mathematics, v. 36, n. 2, p. 8-13. 2016.

ROWLAND, T.; HUCKSTEP, P.; THWAITES, A. Elementary teachers' mathematics subject knowledge: The knowledge quartet and the case of Naomi. Journal of Mathematics Teacher Education, v. 8, p. 255-281, 2005.

SCHMITTAU, J. The role of theoretical analysis in developing algebraic thinking: a Vygotskian perspective. In Cai, J. \& Knuth, D. (eds.), Early Algebraization: A Global Dialogue from Multiple Perspectives, p. 71-85, Springer, 2011.

SHULMAN, L. S. Those who understand: Knowledge growth in teaching. Educational Researcher, v. 15, n. 4, p. 4-14, 1986.

SLOVIN, H.; DOUGHERTY, B. J. Children's conceptual understanding of counting. In Høines, M. J.; Fuglestad, A. B. (eds.), Proceedings of the 28th Conference of the International Group for the Psychology of Mathematics Education, v. 4, p. 209-216. Bergen, Norway: PME, 2004.

STACEY, K. Finding and using patterns in linear generalizing problems. Educational Studies in Mathematics, v. 20, p. 147-164, 1989.

VYGOTSKI, L. S. Mind in Society. The Development of Higher Psychological Processes. Harvard University Press, 1978. 